\title{
Post-cardiotomy ECMO in neonates
}

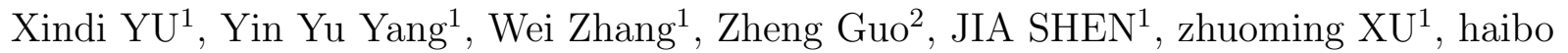 \\ $\mathrm{ZHANG}^{1}$, and Wei Wang ${ }^{1}$ \\ ${ }^{1}$ Shanghai Childrens Medical Center Affiliated to Shanghai Jiaotong University School of \\ Medicine \\ ${ }^{2}$ Affiliation not available
}

September 16, 2020

\begin{abstract}
Background: Extracorporeal membrane oxygenation (ECMO) provides circulatory support in children with congenital heart disease, particularly in the setting of cardiopulmonary failure and inability to wean from cardiopulmonary bypass. This study summarized the clinical application of ECMO in treatment of heart failure after cardiac surgery in neonates. Methods: Clinical data of 23 neonates who received ECMO support in our center from January 2017 to June 2019 were retrospectively analyzed. Results: Twenty-three neonates, aged from 0 to 25 days and weight between 2300 to $4500 \mathrm{~g}$, with heart failure post-cardiotomy were supported with ECMO. The successful weaning rate was $78.26 \%$ and discharge rate was $52.17 \%$. Bleeding and residual malformation were the most common complications. The univariate analysis showed that non-survivors were related to the factors such as higher lactate value of ECMO $12 \mathrm{~h}, 24 \mathrm{~h}(\mathrm{P}=0.008,0.001$, respectively), longer time to lactate normalization $(\mathrm{P}=0.001)$, lactate $>10 \mathrm{mmol} / \mathrm{L}$ before ECMO $(\mathrm{P}=0.01)$, lower weight $(\mathrm{P}=0.01)$, longer ECMO duration $(\mathrm{P}=0.005)$, lower platelet count $(\mathrm{P}=0.001)$, more surgical site bleeding $(\mathrm{P}=0.001)$ and surgical residual malformation $(\mathrm{P}=0.04)$. Further logistic regression analysis revealed that higher lactate value of ECMO 24h $(\mathrm{P}=0.003)$, longer ECMO duration $(\mathrm{P}=0.015)$ and surgical site bleeding $(\mathrm{P}=0.025)$ were independent risk factors. Conclusions: ECMO was an effective technology to support the neonates with cardiopulmonary failure after open-heart surgery. Control the lactate acidosis and surgical site bleeding event may be helpful for patients' recovery.
\end{abstract}

\section{Post-cardiotomy extracorporeal membrane oxygenation in neonates}

Xindi $\mathrm{Yu}^{1}$, MD; Yinyu Yang ${ }^{1}$, MD; Wei Zhang ${ }^{1}$, BD; Zheng Guo ${ }^{1}$, MD; Jia Shen ${ }^{1}$, MD, PhD; Zhuoming $\mathrm{Xu}^{1}, \mathrm{MD}, \mathrm{PhD}$; Haibo Zhang ${ }^{1}, \mathrm{MD}, \mathrm{PhD}$; Wei Wang ${ }^{4}, \mathrm{MD}, \mathrm{PhD}$

${ }^{1}$ Department of Pediatric Thoracic and Cardiovascular Surgery, Shanghai Children's Medical Center, Shanghai Jiaotong University School of Medicine, Shanghai, China.

First author: Xindi Yu, MD. Tel: 01186-13918556546. Email: adusdi@163.com; Address: No1678 Dong Fang Road Shanghai, China, CN 200127.

Corresponding author: Wei Wang, MD, PhD. Tel: 01186-18930830665. Email: wangwei@scmc.com.cn; Address: No1678 Dong Fang Road Shanghai, China, CN 200127.

\section{Author contribution}

Yu Xin-di designed the study and drafed the manuscript, Yang Yin-yu, Zhang Wei, Guo Zheng, Shen Jia, Zhuoming $\mathrm{Xu}$ and Haibo Zhang performed data collection, Wang Wei helped to perform data analysis. All authors read and approved the final manuscript.

Background : Extracorporeal membrane oxygenation (ECMO) provides circulatory support in children with congenital heart disease, particularly in the setting of cardiopulmonary failure and inability to wean 
from cardiopulmonary bypass. This study summarized the clinical application of ECMO in treatment of heart failure after cardiac surgery in neonates.

Methods : Clinical data of 23 neonates who received ECMO support in our center from January 2017 to June 2019 were retrospectively analyzed.

Results : Twenty-three neonates, aged from 0 to 25 days and weight between 2300 to $4500 \mathrm{~g}$, with heart failure post-cardiotomy were supported with ECMO. The successful weaning rate was $78.26 \%$ and discharge rate was $52.17 \%$. Bleeding and residual malformation were the most common complications. The univariate analysis showed that non-survivors were related to the factors such as higher lactate value of ECMO 12h, $24 \mathrm{~h}(\mathrm{P}=0.008,0.001$, respectively $)$, longer time to lactate normalization $(\mathrm{P}=0.001)$, lactate $>10 \mathrm{mmol} / \mathrm{L}$ before ECMO $(\mathrm{P}=0.01)$, lower weight $(\mathrm{P}=0.01)$, longer ECMO duration $(\mathrm{P}=0.005)$, lower platelet count $(\mathrm{P}=0.001)$, more surgical site bleeding $(\mathrm{P}=0.001)$ and surgical residual malformation $(\mathrm{P}=0.04)$. Further logistic regression analysis revealed that higher lactate value of ECMO $24 \mathrm{~h}(\mathrm{P}=0.003)$, longer ECMO duration $(\mathrm{P}=0.015)$ and surgical site bleeding $(\mathrm{P}=0.025)$ were independent risk factors.

Conclusions : ECMO was an effective technology to support the neonates with cardiopulmonary failure after open-heart surgery. Control the lactate acidosis and surgical site bleeding event may be helpful for patients' recovery.

Keywords : Neonate, Extracorporeal membrane oxygenation, Congenital heart disease, Open heart surgery

\section{Introduction}

Extracorporeal membrane oxygenation (ECMO) is an important technology, which can be used for severe heart failure ${ }^{[1-2]}$. Since the first successful ECMO application in a newborn in $1975^{[3]}$, more than 85,000 neonates treated with ECMO have been reported to extracorporeal life support organization (ELSO) nowadays. In China, ECMO has been practiced for two decades, but most patients are adults. As more children undergoing cardiac surgery may require ECMO support for cardio-respiratory failure ${ }^{[4]}$, pediatric ECMO applications have increased and reported in recent years. However, among the numerous studies investigating the utility and risk factors associated with ECMO in pediatric cardiac patients, few specifically address patients with neonate heart disease. In this study, we conducted a retrospective review of neonates who undergone ECMO at Shanghai Children's Medical Center (SCMC) and summarized the clinical application of ECMO in treatment of heart failure after neonatal cardiac surgery.

\section{Materials and methods}

\subsection{Patient characteristics}

The current study was approved by the Institutional Review Board of the Shanghai Children's Medical Center affiliated to Shanghai Jiaotong University School of Medicine. As the study design was a retrospective review of prospectively collected data the need for informed consent was waived. From January 2017 to June 2019, 9354 cases with congenital heart disease (CHD) were undergone open-heart surgery in SCMC and 441 were neonates, 27 cases required support postoperatively (26 VA-ECMO cases, 1 ventricular assist device case). The ventricular assist device infant and three children supported with ECMO less than $24 \mathrm{~h}$ were excluded, and 23 patients ( 15 male, 8 female) was analyzed. Mean age was $9.08 \pm 8.02$ days (range: $0-25$ days) and mean birth weight was $3170 \pm 535 \mathrm{~g}$ (range, 2300-4500 g). The diseases were IAA/COA ( $\mathrm{n}=10)$, D-TGA $(\mathrm{n}=8), \operatorname{PA}(\mathrm{n}=2)$, TAPVC $(\mathrm{n}=1)$, DORV $(\mathrm{n}=1)$, and coronary artery-right ventricular fistula $(\mathrm{n}=1)$.

\subsection{Clinical data}

Successful weaning was defined as weaning without reinsertion of ECMO or death within 24h. Clinical variables were collected: indication of ECMO, ICU details and complications. The lactate clearance time means that the time required for the body's lactate value to fall from the maximum to $<2 \mathrm{mmol} / \mathrm{L}$.

\subsection{Complications}


Complications were categorized: (1) surgical site bleeding (cannulation or surgical site bleeding requiring an intervention); (2) brain injury (central nervous system hemorrhage, infarction causing ischemic injury); (3) gastrointestinal (GI) bleeding (fecal occult blood test is positive, hematemesis, melena or bloody stool); (4) mechanical complication (oxygenator or pump failure, air in circuits); (5) infection (culture positive infection); (6) residual malformation (residual shunt or obstruction, moderate or severe reflux).

\subsection{ECMO management}

The standard circuit includes a centrifugal pump and HI-LITE 800LT hollow-fiber membrane oxygenator. The practice was to start with flow of $130-180 \mathrm{~mL} / \mathrm{kg} / \mathrm{min}$ with the average arterial blood pressure at 40-60 $\mathrm{mmHg}$ and the ventilator was adjusted to rest settings. If neonates experienced severe renal impairment, continuous renal replacement therapy (CRRT) was started immediately.

The standard anticoagulation is unfractionated heparin, ranging 5-40 units/ $\mathrm{kg} / \mathrm{min}$ was administered to keep activated clotting time level at 160-200 seconds and activated partial thromboplastin time between 50 and 70 seconds. The blood components were transfused if hematocrit $<35 \%$, platelet (PLT) count $<$ $50 \times 10^{9} / \mathrm{L}$, and fibrinogen $<1.5 \mathrm{~g} / \mathrm{L}$.

With the improvement of the clinical condition, if the neonate's hemodynamic status was stable at 50 $\mathrm{mL} / \mathrm{kg} / \mathrm{min}$ pump flow, decannulation was anticipated.

\subsection{Statistical analysis}

Statistical analysis was performed using SPSS22 for windows. Quantitative variables are presented as mean \pm standard deviation when normally distributed, or as median (interquartile range, IQR) if non-normally distributed. Independent t-test and chi-square test were used to compare baseline characteristics between groups. We used univariate analysis and multivariable logistic regression to evaluate the risk factors with non-survivors. $\mathrm{P}<0.05$ were considered statistically significant.

\section{Results}

\subsection{Characteristics (Table 1)}

Twenty-three neonates with heart failure after open heart surgery were undergone ECMO, and 2 were premature infants and 3 were less than 2500g. Eighteen cases(78.26\%)were weaned off ECMO and $12(52.17 \%)$ discharged successfully.

The indications were categorized into extracorporeal cardiopulmonary resuscitation (ECPR), inability to wean from cardiopulmonary bypass (CPB), low cardiac output syndrome (LCOS) in 8, 5, 10 cases. Of the ECPR neonates, 4 patients discharged (hypoperfusion time [?]30min), and 4 cases died finally (hypoperfusion time $>30 \mathrm{~min})(\mathrm{p}=0.005)$. Five neonates, inability to wean from $\mathrm{CPB}$, were weaned successfully, just one survived. Ten cases had LCOS, 9 (90\%) were weaned successfully and 7 (70\%) discharged.

The duration of ECMO support was between $38 \mathrm{~h}$ and 456 hours. There were 8 neonates weaned off ECMO in 3 days and 5 cases survived; 9 patients between 3-5 days and 7 survived; 6 neonates above 5 days and all died $(\mathrm{P}=0.01)$.

\section{2 outcomes (Table 2 )}

Compared with the survivors, the weights of the non-survivors were lighter $(3.11+-0.67$ vs $3.43+-0.49 \mathrm{~kg}$, $\mathrm{P}=0.01)$, and ECMO duration (145.09+-90.38 vs $78.92+-17.36 \mathrm{~h}, \mathrm{P}=0.046)$ was significantly longer. The non-survivors had less time after surgery to ECMO ( $7.01+-3.15$ vs $9.25+-4.28 \mathrm{~h}, \mathrm{P}=0.03)$, higher the highest lactate levels $(18.34+-5.13$ vs $13.87+-4.19 \mathrm{mmol} / \mathrm{L}, \mathrm{P}=0.03)$, higher lactate value of ECMO $12 \mathrm{~h}(9.24+-$ 3.70 vs $4.76+-2.49 \mathrm{mmol} / \mathrm{L}, \mathrm{P}=0.005)$, $24 \mathrm{~h}(5.36+-2.13$ vs $2.27+-1.05 \mathrm{mmol} / \mathrm{L}, \mathrm{P}=0.001)$, more time to lactate normalization $(59.34+-21.15$ vs $25.01+-13.50 \mathrm{~h}, \mathrm{P}=0.036)$, higher peak creatinine values(151.29+68.28 vs $70.54+-30.66 \mathrm{mg} / \mathrm{dL}, \mathrm{P}=0.03)$ and blood transfusion volume $(275.86+-100.90 \mathrm{vs} 88.51+-30.24 \mathrm{ml} / \mathrm{d}$, $\mathrm{P}=0.04)$. The lowest PLT count was significantly lower in non-survivors than survivors $(\mathrm{P}=0.03)$. The relationship between surgical site bleeding, lactic acid $>10 \mathrm{mmol} / \mathrm{L}$ before ECMO and residual malformation 
on non-survivors was statistically significant ( $\mathrm{P}=0.002,0.01,0.04$, respectively). There was no statistical difference between CPB time, clamp time, the peak ALT and AST values, intracranial hemorrhage, GI bleeding, renal failure and ECPR $(\mathrm{P}>0.05)$.

\subsection{Univariate and logistic regression analysis results (Table 3)}

The univariate analysis showed that non-survivors were related to the factors higher lactate value of ECMO $12 \mathrm{~h}, 24 \mathrm{~h}(9.24+-3.70$ vs $4.76+-2.49 \mathrm{mmol} / \mathrm{L}, \mathrm{P}=0.008$ and $5.36+-2.10$ vs $2.27+-1.05 \mathrm{mmol} / \mathrm{L}, \mathrm{P}=0.001$, respectively), longer time to lactate normalization $(59.34+-21.13$ vs $25.01+-13.50 \mathrm{~h}, \mathrm{P}=0.001)$, lower weight $(3.11+-0.67$ vs $3.43+-0.49 \mathrm{~kg}, \mathrm{P}=0.001)$, longer ECMO time $(145.02+-90.25$ vs $78.92+-17.31 \mathrm{~h}, \mathrm{P}=0.005)$, lower the lowest PLT count (30.90+-18.14 vs $\left.48.10+-20.03 \times 10^{9} / \mathrm{L}, \mathrm{P}=0.001\right)$, more surgical site bleeding (11vs5, $\mathrm{P}=0.001$ ) and surgical residual malformation (5vs1, $\mathrm{P}=0.04$ ). Further logistic regression analysis revealed that higher lactate value of ECMO 24h $(\mathrm{P}=0.003)$, longer ECMO duration $(\mathrm{P}=0.015)$ and more surgical site bleeding event $(\mathrm{P}=0.025)$ were independent risk factors for non-survivors.

\section{4 causes of death}

The mortality rate was $47.83 \%$ (11/23), six neonates were weaned successfully but died finally. Among the six patients, 5 had residual anatomical problems, even the heart function recovered during ECMO, but follow-up wasn't sustainable. Three cases involved GI bleeding with unstable circulatory function. Two cases failed to undergo further correction for renal failure, medical cost and heart failure reasons, no further interventions were provided and eventually both of them failed to wean.

\subsection{Complications (Table 2)}

\subsubsection{Surgical site bleeding}

Major bleeding requiring re-exploration occurred in 16 (69.57\%) patients. Eleven (68.75\%) patients were explored in the first $24 \mathrm{~h}$. Five had no initial major bleeding but required exploration later in the ECMO run for "late bleeding". Survival rate in the explored group was $5(31.25 \%)$. Survival rates for early bleeding versus late bleeding were $25 \%$ and $6.25 \%(\mathrm{P}=0.51)$.

\subsubsection{Nervous system injury}

Ten $(43.48 \%)$ babies had central nervous system injury, but only 6 survived. Overall neurological injury included intracranial bleeding $(\mathrm{n}=8,34.78 \%)$ and ischemic brain injury $(\mathrm{n}=2,8.70 \%)$. Five cases had neurological bleeding and surgical site bleeding simultaneously.

\subsubsection{Renal failure}

The incidence of renal failure requiring CRRT was 5 (21.74\%), only two patients survived. None of the survivors required long-term dialysis after hospital discharge $(\mathrm{P}=0.53)$.

\subsubsection{GI bleeding}

GI bleeding was a serious complication. Among these 4 cases, only 1 baby survived. Two (50\%) neonates needed laparotomies, but failed to undergo further correction.

\subsubsection{Other complications}

Other complications included cardiac tamponade $(\mathrm{n}=5,21.74 \%)$, arrhythmia $(\mathrm{n}=4,17.39 \%)$, liver function damage $(\mathrm{n}=4,17.39 \%)$, infection $(\mathrm{n}=3,13.04 \%)$, and clots in the ECMO circuit $(\mathrm{n}=2,8.70 \%)$.

\subsection{Residual anatomical malformation}

Another serious issue was residual anatomical problems $(26.09 \%, \mathrm{n}=6)$. Only one patient who undergone re-operation survived. Three patients involved residual ventricular septal shunt and residual aortic arch obstruction, and two cases had postoperative aortic valve insufficiency. Although several cases weaned successfully, but died finally due to recurrent heart failure. 


\section{Discussion}

ECMO is commonly used in pediatric patients with CHD, particularly in the setting of low-output failure, arrhythmia, cardiopulmonary arrest, or inability to transition from $\mathrm{CPB}{ }^{[5]}$.However, despite significant advances in ECMO techniques and management over the last several years, prognosis remains poor ${ }^{[6]}$. The underlying causes of death vary from cardiovascular events to organ failure, including GI, renal, neurologic, coagulation, and it carries a significant cost burden ${ }^{[7]}$. Neonates are special population, who's cardiomyocytes are softer with less contractile tissue and lower energy reserves. Longer CPB time leads to poor myocardial cell compliance and insensitivity to drugs, and these lead to heart failure controlled by drugs difficultly after open-heart surgery. According to the latest statistics from ELSO 2017, the neonatal survival rate of CHD is $47 \%$ and discharge rate is $39 \%{ }^{[8]}$. In our study, although the survival rate of neonate is as high as $52.17 \%$, there are many risk factors that affect the outcomes.

\subsection{Metabolic acidosis}

Studies have shown that hyper-lactic acidosis is an effective biomarker, and the severity of pre-ECMO arterial acidosis is related to outcomes ${ }^{[9]}$. In our study, 5 patients with lactic acid $<10 \mathrm{mmol} / \mathrm{L}$ before ECMO were discharged, while in 18 neonates with lactic acid $>10 \mathrm{mmol} / \mathrm{L}$, only 7 survived. This suggests that higher lactate levels before ECMO is an independent risk factor for poor outcomes. There was a significant difference in the highest lactate, the levels of ECMO $12 \mathrm{~h}$ and $24 \mathrm{~h}$, the lactate clearance time between two groups ( $\mathrm{P}=0.03,0.005,0.001,0.036$, respectively). The results are similar to those findings of the reports ${ }^{[10,11]}$. The Fux ${ }^{[12]}$ team analyzed VA-ECMO patients and found that ischemic heart disease and arterial lactate were independent predictors of 90-day mortality; The 90-day survival rate of lactic acid $>10$ $\mathrm{mmol} / \mathrm{L}$ was lower than patients with lactic acid $<10 \mathrm{mmol} / \mathrm{L}$ before ECMO $(13 \%$ and $55 \%, \mathrm{P}<0.001)$. If the lactate remained at $3 \mathrm{mmol} / \mathrm{L}$ after $48 \mathrm{~h}$, the 30 -day mortality rate is $52 \%$. Other papers ${ }^{[13,14]}$ suggested that persistent metabolic acidosis after ECMO reflect the severity of ischemia and hypoxia and confirmed that the peak lactate level affects the survival rate. Therefore, early application to reverse poor perfusion and prevention high lactate are critical factors for successful outcomes following ECMO.

\subsection{ECMO duration}

Our findings are consistent with the results reported in the literature on ECMO support after cardiac surgery [14]: Compared with the survivors, ECMO duration were significantly longer in non-survivals $(\mathrm{p}=0.046)$. ECMO duration is directly linked to the other complications and survival rate. The ELSO data analysis also showed that ${ }^{[15]}$ : The highest survival rate for the ECMO weaning is at the fourth day, and the shorter ECMO duration resulted in higher mortality due to inadequate support. In the group of neonates assisted for 4-12 days, the survival rate decreased gradually with the longer duration, especially in children with assist time $>7$ days ${ }^{[13]}$. Long-term assistance means poor recovery of heart function, especially in neonates after cardiac surgery. If accompanied with serious complications, ECMO couldn't successfully wean off in short term, long-term assist devices or transition to heart transplantation should be considered ${ }^{[16]}$. In this group, there were 8 children with assist time of 1-3 days and 5 survived, 9 cases assisted for 3-5 days and 7 cases discharged; however, 6 patients assisted for more than 5 days all died $(\mathrm{P}=0.01)$. Our results were close to the ELSO statistics, indicating that ECMO duration was one of the main factors affecting survival.

\subsection{Bleeding}

Complications in the ECMO support are important predictors of poor outcomes. The most common complication was bleeding of this study. Sixteen cases experienced severe surgical site bleeding requiring explorations and 11 cases died. Neonates have small volume of circulating blood and immature blood coagulation mechanism, ECMO prefilling dilute the anticoagulant components and longer CPB time destroyed blood components. Improving supplement coagulation components and try to correct coagulation defects are very important ${ }^{[13]}$. There were four cases experienced severe GI bleeding and only one survived, and two cases with ECPR time greater than 30min before ECMO. GI bleeding resulted from infection, ischemia and hypoxia, feeding and blood flow to premature labor when patients under critical illness. Studies have shown that 90\%-95\% necrotizing enterocolitis (NEC) occurs in premature and low birth weight infants with a ges- 
tational age of less than 36 weeks, which is the result of a combination of risk factors ${ }^{[17]}$. The literature believes that feeding factors (type, speed and concentration) are intrinsically linked to the occurrence of NEC, because the neonatal digestive system is immature and susceptible to ischemic injury; and digestive enzyme activity is low, which will eventually increase the incidence of NEC ${ }^{[18]}$.

\subsection{Residual malformations}

Residual cardiac malformations were found in 6 cases by transthoracic echocardiography. One neonate's malformation was corrected during ECMO and discharged. Other patients were weaned successfully, but died finally due to recurrent heart failure. There was a statistically significant difference between the survival

and non-survivals $(\mathrm{P}=0.04)$. Studies ${ }^{[19,20]}$ have reported that one-quarter of children with ECMO support after open open-heart surgery have residual anatomical problems. All residual lesions should be evaluated actively, early examination and interventional therapy were related to better clinical outcomes. Therefore, residual malformations should be discovered as soon as possible, and active intervention can improve cardiac function.

\section{Summary}

ECMO was an effective technology to support the neonates with cardiopulmonary failure after open-heart surgery to wait for heart function recovery. Control the lactate acidosis and surgical site bleeding event may be helpful for patients' recovery.

Funding: None.

The authors declare no conflicts of interests.

Consent for publication: Not applicable.

\section{References}

1.Torres-Andres F, Fink EL, Bell MJ, Sharma MS, Yablonsky EJ, Sanchez-de-Toledo J. Survival and LongTerm Functional Outcomes for Children with Cardiac Arrest Treated with Extracorporeal Cardiopulmonary Resuscitation. Pediatr Crit Care Med 2018; 05: 19(5).

2.Wallinder A, Pellegrino V, Fraser JF, et al. ECMO as a bridge to non-transplant cardiac surgery. J Card Surg 2017;32(8).

3. Bartlett RH, Gazzaniga AB, Jefferies MR, et al. Extracorporeal membrane oxygenation (ECMO) cardiopulmonary support in infancy. Trans Am Soc Artif Intern Organs 1976; 22: 80-93.

4. Azizov F, Merkle J, Fatullayev J, et al. Outcomes and factors associated with early mortality in pediatric and neonatal patients requiring extracorporeal membrane oxygenation for heart and lung failure. $J$ Thorac Dis 2019;11 (Suppl 6): S871-S888.

5. Burke CR, McMullan DM. Extracorporeal life support for pediatric heart failure. Front Pediatr 2016; 4: 115.

6. Erdil T, Lemme F, Konetzka A, et al. Extracorporeal membrane oxygenation support in pediatrics. Ann Cardiothorac Surg. 2019; 8(1): 109-115.

7. Djordjevic I, Sabashnikov A, Deppe AC, et al. Risk factors associated with 30-day mortality for out-ofcenter ECMO support: experience from the newly launched ECMO retrieval service. J Artif Organs. 2019; 22(2): $110-117$.

8. Thiagarajan RR, Barbaro RP, Rycus PT, et al. ELSO member centers. Extracorporeal Life Support Organization Registry International Report 2016. ASAIO 2017, 63(1): 160-67.

9. Avalli L, Sangalli F, Migliari M, et al. Early vascular complications after percutaneous cannulation for extracorporeal membrane oxygenation for cardiac assist. Minerva Anestesiol 2016; 82: 36-43. 
10. Choi MS, Sung K, Cho YH. Clinical Pearls of Venoarterial Extracorporeal Membrane Oxygenation for Cardiogenic Shock. Korean Circ J. 2019; 49(8): 657-677.

11. Napp LC, Kuhn C, Bauersachs J. ECMO in cardiac arrest and cardiogenic shock. Herz. 2017; 42(1): $27-44$.

12. Fux T, Holm M, Corbascio M, Lund LH, van der Linden J. Venoarte-rial extracorporeal membrane oxygenation for postcardiotomy shock: risk for mortality. Thorac Cardiovasc Surg 2018; 156: 1894-902.

13. Alsoufi B, Awan A, Manlhiot C, et al. Does Single Ventricle Physiology Affect Survival of Children Requiring Extracorporeal Membrane Oxygenation Support Following Cardiac Surgery? World Journal for Pediatric and Congenital Heart Surgery 2014, Vol 5(1): 7-15.

14. Gupta P, Robertson MJ, Rettiganti M, et al. Impact of Timing of ECMO Initiation on Outcomes After Pediatric Heart Surgery: A Multi-Institutional Analysis. Pediatric cardiology 2016; 37(5): 971-8.

15. Smith M, Vukomanovic A, Brodie D, Thiagarajan R, Rycus P, Buscher H. Duration of venoarterial extracorporeal life support (VA ECMO) support and outcome: an analysis of the Extracorporeal Life Support Organization (ELSO) registry. Crit Care 2017; 21: 45.

16. Gabriela A. Kuraim, Daniel Garros, Lindsay Ryerson, et al. Predictors and outcomes of early postoperative veno-arterial extracorporeal membrane oxygenation following infant cardiac surgery. J of Intensive Care 2018, 6:56.

17. Teiserskas J,Bartasiene R, Tameliene R. Associations between red blood cell transfusions and necrotizing enterocolitis in very low birth weight infants: ten-year data of a tertiary neonatal unit. Medicina (Kaunas) 2019,55(1): E16.

18. Patel RM,Knezevic A,Shenvi N,et al. Association of red blood cell transfusion,anemia,and necrotizing enterocolitis in very low- birth-weight infants. JAMA, 2016, 315(9): 889-897.

19. Hemant, Agarwal H S, Hardison D C, et al. Residual lesions in postoperative pediatric cardiac surgery patients receiving extracorporeal membrane oxygenation support. Thorac Cardiovasc Surg 2014; 147: 43441.

20. Guo Z, Yang Y, Zhang W, et al. Extracorporeal cardiopulmonary resuscitation in children after open heart surgery. Artif Organs. 2019; 43(7): 633-640.

Table1. Clinical characteristics

\begin{tabular}{lllll}
\hline Classification & Overall $(\mathrm{N}=23), \%$ & $\begin{array}{l}\text { Survivors }(\mathrm{N}=12), \\
\%\end{array}$ & $\begin{array}{l}\text { Non-survivors } \\
(\mathrm{N}=11), \%\end{array}$ & P value \\
$\begin{array}{l}\text { Gender } \\
\text { Male }\end{array}$ & 15 & $7(58.33)$ & $8(72.73)$ & 0.46 \\
Female & 8 & $5(41.67)$ & $3(27.27)$ & \\
Body Weight $(\mathrm{kg})$ & & & & 0.098 \\
{$[?] 2.49$} & $3(13.04)$ & $1(8.33)$ & $2(18.18)$ & \\
$2.50-2.99$ & $6(26.09)$ & $1(8.33)$ & $5(45.45)$ & \\
$3-3.99$ & $12(52.17)$ & $8(66.66)$ & $4(36.36)$ & \\
{$[?] 4$} & $2(8.70)$ & $2(16.67)$ & 0 & \\
Age $(\mathrm{d})$ & & & & \\
Premature Baby & $2(8.70)$ & $1(8.33)$ & $1(9.09)$ & \\
$<7$ & $9(39.13)$ & $7(58.33)$ & $2(18.18)$ & \\
$7-14$ & $6(26.09)$ & $1(8.33)$ & $5(45.45)$ & \\
$14-30$ & $6(26.09)$ & $3(25)$ & $3(27.27)$ & \\
Cardiac Defect & & & $4(36.36)$ & \\
CoA/IAA/VSD & $10(43.48)$ & $6(50)$ &
\end{tabular}




\begin{tabular}{|c|c|c|c|c|}
\hline TGA & $8(34.78)$ & $5(41.67)$ & $3(27.27)$ & \\
\hline TAPVC & $1(4.35)$ & 0 & $1(9.09)$ & \\
\hline $\mathrm{PA} / \mathrm{IVS}$ & $2(8.70)$ & $1(8.33)$ & $1(9.09)$ & \\
\hline DORV & $1(4.35)$ & 0 & $1(9.09)$ & \\
\hline Coronary & $1(4.35)$ & 0 & $1(9.09)$ & \\
\hline \multicolumn{5}{|l|}{ Artery-right } \\
\hline \multicolumn{5}{|l|}{ Ventricular } \\
\hline \multicolumn{5}{|l|}{ Fistula } \\
\hline Indication & & & & 0.18 \\
\hline LCOS & $10(43.48)$ & $7(58.33)$ & $3(27.27)$ & \\
\hline Unable to Wean & $5(21.74)$ & $1(8.33)$ & $4(36.36)$ & \\
\hline \multicolumn{5}{|l|}{ Off CPB } \\
\hline ECPR & $8(34.78)$ & $4(33.33)$ & $4(36.36)$ & \\
\hline Hypoperfusion & & & & 0.005 \\
\hline \multicolumn{5}{|l|}{ Time (min) } \\
\hline [?]30 & $4(16.67)$ & $4(30.77)$ & 0 & \\
\hline$>30$ & $4(16.67)$ & 0 & $4(36.36)$ & \\
\hline $\begin{array}{l}\text { ECMO Duration } \\
\text { (d) }\end{array}$ & & & & 0.01 \\
\hline $1-3$ & $8(34.78)$ & $5(41.67)$ & $3(27.27)$ & \\
\hline $3-5$ & $9(39.13)$ & $7(58.33)$ & $2(18.18)$ & \\
\hline$>5$ & $6(26.09)$ & 0 & $6(54.55)$ & \\
\hline Successful & $18(78.26)$ & $12(100)$ & $6(54.55)$ & \\
\hline Weaning & & & & \\
\hline
\end{tabular}

COA, coarctation of the aorta; DORV, double outlet right ventricle; IAA, interrupted aortic arch; PA/IVS, pulmonary atresia with intact ventricular septum; TAPVC, total anomalous pulmonary venous connection; TGA, transposition of the great arteries; VSD, ventricular septal defect.

Table2. Comparison of clinical information between two groups

\begin{tabular}{lllll}
\hline Classification & Overall $(\mathrm{N}=23)$ & Survivors $(\mathrm{N}=12)$ & $\begin{array}{l}\text { Non-survivors } \\
(\mathrm{N}=11)\end{array}$ & P value \\
Weight $(\mathrm{kg})$ & $3.17 \pm 0.53$ & $3.43 \pm 0.49$ & $3.11 \pm 0.67$ & 0.01 \\
CPB Time(min) & $168.48 \pm 93.70$ & $155.45 \pm 54.14$ & $185.93 \pm 134.37$ & 0.23 \\
$\begin{array}{l}\text { Clamp Time } \\
\text { (min) }\end{array}$ & $90.22 \pm 53.92$ & $88.91 \pm 15.52$ & $97.23 \pm 74.28$ & 0.55 \\
$\begin{array}{l}\text { ECMO Duration } \\
\text { (h) }\end{array}$ & $109.48 \pm 63.03$ & $78.92 \pm 17.36$ & $145.09 \pm 90.38$ & 0.046 \\
$\begin{array}{l}\text { Ventilator } \\
\begin{array}{l}\text { Duration (d) } \\
\text { ICU Duration (d) }\end{array}\end{array}$ & $12.92 \pm 4.45$ & $16.42 \pm 4.74$ & $10.82 \pm 3.91$ & 0.035 \\
$\begin{array}{l}\text { Length Of } \\
\text { Hospitalization(d) }\end{array}$ & $24.25 \pm 9.79$ & $23.83 \pm 8.72$ & $10.39 \pm 5.76$ & 0.007 \\
$\begin{array}{l}\text { Time After } \\
\text { Surgery To }\end{array}$ & $9.01 \pm 3.80$ & $34.83 \pm 11.73$ & $11.64 \pm 7.63$ & 0.01 \\
$\begin{array}{l}\text { ECMO(h) } \\
\text { The Highest }\end{array}$ & $15.03 \pm 4.97$ & $9.25 \pm 4.28$ & $7.01 \pm 3.15$ & 0.03 \\
Lactate (mmol/L) & & & & \\
& & $13.87 \pm 4.19$ & $18.34 \pm 5.13$ & 0.03
\end{tabular}




\begin{tabular}{|c|c|c|c|c|}
\hline $\begin{array}{l}\text { Lactate Of } \\
\text { ECMO } 12 \mathrm{~h} \\
(\mathrm{mmol} / \mathrm{L})\end{array}$ & $6.34 \pm 3.41$ & $4.76 \pm 2.49$ & $9.24 \pm 3.70$ & 0.005 \\
\hline $\begin{array}{l}\text { Lactate Of } \\
\text { ECMO } 24 \mathrm{~h} \\
(\mathrm{mmol} / \mathrm{L})\end{array}$ & $3.33 \pm 1.78$ & $2.27 \pm 1.05$ & $5.36 \pm 2.13$ & 0.001 \\
\hline $\begin{array}{l}\text { Time to Lactate } \\
\text { Normalization ( } 22 \\
\mathrm{mmol} / \mathrm{L}, \mathrm{h})\end{array}$ & $40.29 \pm 18.46$ & $25.01 \pm 13.50$ & $59.34 \pm 21.15$ & 0.036 \\
\hline $\begin{array}{l}\text { Peak } \\
\text { Creatinine }(\mathrm{mg} / \mathrm{dL})\end{array}$ & $119.22 \pm 50.49$ & $70.54 \pm 30.66$ & $151.29 \pm 68.28$ & 0.03 \\
\hline Peak ALT(IU/L) & $44.06 \pm 30.15$ & $36.20 \pm 26.02$ & $51.32 \pm 38.52$ & 0.12 \\
\hline Peak AST(IU/L) & $201.83 \pm 133.56$ & $156.88 \pm 121.71$ & $238.27 \pm 169.50$ & 0.26 \\
\hline $\begin{array}{l}\text { Lowest PLT } \\
\text { Count }\left(\times 10^{9} / \mathrm{L}\right)\end{array}$ & $38.05 \pm 18.77$ & $48.10 \pm 20.03$ & $30.90 \pm 18.14$ & 0.03 \\
\hline $\begin{array}{l}\text { Blood } \\
\text { Transfusion(ml/d) }\end{array}$ & $193.77 \pm 97.18$ & $88.51 \pm 30.24$ & $275.86 \pm 100.90$ & 0.04 \\
\hline $\begin{array}{l}\text { PLT } \\
\text { Transfusion(ml/d) }\end{array}$ & $70.87 \pm 36.28$ & $55.01 \pm 22.82$ & $86.43 \pm 42.2$ & 0.31 \\
\hline $\begin{array}{l}\text { FFP And Plasma } \\
\text { Transfusion }(\mathrm{ml} / \mathrm{d})\end{array}$ & $168.56 \pm 67.64$ & $98.00 \pm 55.76$ & $247.14 \pm 86.35$ & 0.18 \\
\hline $\begin{array}{l}\text { Surgical Site } \\
\text { Bleeding }[\mathrm{n}(\%)]\end{array}$ & $16(69.57)$ & $5(41.66)$ & $11(100)$ & 0.002 \\
\hline $\begin{array}{l}\text { Intracranial } \\
\text { Hemorrhage [n } \\
(\%)]\end{array}$ & $10(43.48)$ & $6(50)$ & $4(36.36)$ & 0.50 \\
\hline $\operatorname{ECPR}[\mathrm{n}(\%)]$ & $8(34.78)$ & $4(33.33)$ & $4(36.36)$ & 0.87 \\
\hline $\begin{array}{l}\text { Pre-ECMO } \\
\text { Lactate }<10 \\
\mathrm{mmol} / \mathrm{L}[\mathrm{n}(\%)]\end{array}$ & $5(21.74)$ & $4(33.33)$ & 1(9.09) & 0.10 \\
\hline $\begin{array}{l}\text { Pre-ECMO } \\
\text { Lactate }>10 \\
\text { mmol/L }[\mathrm{n}(\%)]\end{array}$ & $18(78.26)$ & $7(58.33)$ & $11(100)$ & 0.01 \\
\hline $\begin{array}{l}\text { Surgical Residual } \\
\text { Malformation [n } \\
(\%)]\end{array}$ & $6(26.09)$ & $1(8.33)$ & $5(45.45)$ & 0.04 \\
\hline $\begin{array}{l}\text { Renal Failure [n } \\
(\%)]\end{array}$ & $5(21.74)$ & $2(16.67)$ & $3(27.27)$ & 0.53 \\
\hline $\begin{array}{l}\text { GI Bleeding }[\mathrm{n} \\
(\%)]\end{array}$ & $4(17.39)$ & $1(8.33)$ & $3(27.27)$ & 0.23 \\
\hline
\end{tabular}

Table3. Univariate Analysis and Multivariate Logistic Regression Results

\begin{tabular}{llllllll}
\hline Classification & Survivors & $\begin{array}{l}\text { Non- } \\
\text { survivors }\end{array}$ & $\begin{array}{l}\text { Univariate } \\
\text { Analysis }\end{array}$ & $\begin{array}{l}\text { Univariate } \\
\text { Analysis }\end{array}$ & $\begin{array}{l}\text { Multivariate } \\
\text { Logistic }\end{array}$ & $\begin{array}{l}\text { Multivariate } \\
\text { Logistic }\end{array}$ & $\begin{array}{l}\text { Multivariate } \\
\text { Logistic }\end{array}$ \\
& & & Fegression & $\begin{array}{l}\text { Regression } \\
\text { Regression }\end{array}$ \\
Weight & $3.43 \pm 0.49$ & $3.11 \pm 0.67$ & 7.90 & P & 0.01 & & OR \\
(kg) & & & & & & & \\
\end{tabular}




\begin{tabular}{|c|c|c|c|c|c|c|c|}
\hline $\begin{array}{l}\text { ECMO } \\
\text { Duration } \\
\text { (h) }\end{array}$ & $78.92 \pm 17.31$ & $145.02 \pm 90.25$ & 9.62 & 0.005 & 0.75 & $0.59,1.04$ & 0.015 \\
\hline $\begin{array}{l}\text { Time after } \\
\text { Surgery to } \\
\text { ECMO } \\
\text { (h) }\end{array}$ & $9.25 \pm 4.28$ & $7.01 \pm 3.15$ & 1.46 & 0.24 & & & \\
\hline $\begin{array}{l}\text { The } \\
\text { Highest } \\
\text { Lactate } \\
(\mathrm{mmol} / \mathrm{L})\end{array}$ & $13.87 \pm 4.19$ & $18.34 \pm 5.13$ & 1.83 & 0.19 & & & \\
\hline $\begin{array}{l}\text { Lactate of } \\
\text { ECMO } \\
12 \mathrm{~h} \\
(\mathrm{mmol} / \mathrm{L})\end{array}$ & $4.76 \pm 2.49$ & $9.24 \pm 3.70$ & 8.55 & 0.008 & 2.55 & $0.42,15.33$ & 0.38 \\
\hline $\begin{array}{l}\text { Lactate of } \\
\text { ECMO } \\
24 \mathrm{~h} \\
(\mathrm{mmol} / \mathrm{L})\end{array}$ & $2.27 \pm 1.05$ & $5.36 \pm 2.10$ & 101.41 & 0.001 & 13.87 & $2.33,18.84$ & 0.003 \\
\hline $\begin{array}{l}\text { Time to } \\
\text { Lactate Nor- } \\
\text { malization } \\
\text { (i2 mmol/L, } \\
\text { h) }\end{array}$ & $25.01 \pm 13.50$ & $59.34 \pm 21.13$ & 22.75 & 0.001 & 3.88 & $0.26,1.06$ & 0.051 \\
\hline $\begin{array}{l}\text { Peak } \\
\text { Creatinine } \\
(\mathrm{mg} / \mathrm{dL})\end{array}$ & $70.54 \pm 30.66$ & $151.29 \pm 65.28$ & 2.98 & 0.10 & & & \\
\hline $\begin{array}{l}\text { Lowest PLT } \\
\text { Count }(\times \\
\left.10^{9} / \mathrm{L}\right)\end{array}$ & $48.10 \pm 20.03$ & $30.90 \pm 18.14$ & 42.51 & 0.001 & 3.62 & $0.82,1.10$ & 0.057 \\
\hline $\begin{array}{l}\text { Blood } \\
\text { Transfu- } \\
\text { sion } \\
(\mathrm{ml} / \mathrm{d})\end{array}$ & $88.51 \pm 30.24$ & $275.86 \pm 100.90$ & 5.11 & 0.05 & & & \\
\hline $\begin{array}{l}\text { Surgical } \\
\text { Site } \\
\text { Bleeding } \\
{[\mathrm{n}(\%)]}\end{array}$ & $5(41.66)$ & 11(100) & 16.13 & 0.001 & 7.41 & $1.28,43.41$ & 0.03 \\
\hline $\begin{array}{l}\text { Pre- } \\
\text { ECMO } \\
\text { Lac- } \\
\text { tate }>10 \\
\mathrm{mmol} / \mathrm{L} \\
{[\mathrm{n}(\%)]}\end{array}$ & $7(58.33)$ & 11(100) & 3.35 & 0.08 & & & \\
\hline $\begin{array}{l}\text { Surgical } \\
\text { Residual } \\
\text { Malforma- } \\
\text { tion [n } \\
(\%)]\end{array}$ & $1(8.33)$ & $5(45.45)$ & 5.12 & 0.04 & & & \\
\hline
\end{tabular}

